\title{
FEAR, HONOUR AND SHAME. HORROR FICTIONS OF THE 1950s AND 1960s
}

\section{Mare Kõiva}

\begin{abstract}
The article analyses horror stories and legends about a sausage factories and about a woman who killed her children at her lover's insistence, told in a small Estonian town in the 1950s and 1960s. Presenting one's self and memories is often a strategy for altering data. Certain events or stereotypic stories of fear, dishonouring or shame can be told as first-person narratives on the condition that these do not damage the person's honour. Fear, honour and shame are terms openly or implicitly discussed in many forms of verbal art, and are also present in personal narratives.

Keywords: Fear, shame, honour, personal experience narratives, socialism, Põltsamaa
\end{abstract}

Honor and shame from no condition rise. Act well your part: there all the honor lies. Alexander Pope

Fear, honour and shame are terms openly or implicitly discussed in many forms of verbal art and can be also met in personal narratives. These same terms are related to stereotypic beliefs and attitudes, some of which we still meet in everyday expressions today. Honour and shame, and also fear, are related to unwritten and written legal norms in a community, while the first two are simultaneously important bonds linking the individual to the community, shaping his image and thus influencing his career.

In the 1990s I became interested in children's horror stories. Some of these stories had left a deep impression on me in my childhood, comparable to the impression their childhood monsters had left on the characters of the short story Ghost no. 5. At the time I was interested in the structure and characters of children's stories, how stable or labile the stories were, but the stories also enchanted me with their playfulness and the profound way in which they differed from adults' horror stories of similar content - though the adults' stories were based on profound belief (Kõiva 1998, see also Pakalns 1995, 2004). Later, having studied urban legends, personal narratives, memoirs from Soviet Estonia, I have come to realise that presenting one's self and memo- 
ries are often a strategy for altering data. It is very common that variations are based on different experiences and there are many possible ways of recalling or recounting an experience.

In the present article will discuss horror stories told in a small town in the 1950s and 1960s: first of all, the expression of fears concerning personal existence in stories and a series of stories about a woman who killed her children at her lover's insistence, as well as stories about blood takers and sausage makers. For source material, I have used records of the Estonian Folklore Archives, memoirs by the local priest Herbert Kuurme (Kuurme $2001 \mathrm{a}, \mathrm{b})$, personal interviews from more recent times and personal memories. I have attempted to choose locations that are known to me from my friends or that I have been to myself. All this because the very simple reason that there exists no simple uniform Soviet time. I was intrigued to find out why and how do some events become legends while others are forgotten.

During field work and interviews it is easily noticed that even the most fantastic fictions can be narrated as true experience stories and as first-person narratives, while there are topics and plots that are unerringly attributed even not to acquaintances but to anonymous characters, constituting heterodiegetic narratives. The article poses four principal hypotheses:

Firstly, homodiegetic narratives are governed by the established social norms and the role the narrator places himself in. Narrating to a wider audience, the narrator never places himself in a socially unfavourable position that could damage his honour or cause falling into shame, and be condemned by his closer social circle. This is avoided even in the case of an explicitly fictional story.

Secondly, the social values and value systems of social groups are conservative, oral legal contracts are long-lasting and deviation from these is sanctioned. In every society there are rumours that a story's characters, narrators and listeners are sensitive to, as these violate the common code of honour.

Thirdly, certain events or stereotypic stories of fear, shaming or shame can be told in the first person on the condition that these do not damage the person's honour. That is to say, they allow the 
main character to place himself not in the psychologically and intuitively condemned role of a defenceless victim of violence, but rather in the role of a hero or martyr - someone who has escaped a complicated situation, a small hero.

Fourthly, although certain narrative types and motifs have a long history, it is important to place the story into the system of contemporary symbols and values, the system of social, economical and political relations. Only this can help to understand the underlying reason for the spread of the story. This is also necessary to avoid over-mythologisation.

\section{Põltsamaa - a small town in Central Estonia}

As already mentioned, the article discusses a place I know well Põltsamaa, a small town in Central Estonia, which has, on a number of occasions throughout history, functioned as an important centre owing to its geographical location and, even more importantly, owing to the people who have constructed the mentality of the region. At times, Põltsamaa has also been an important centre of power. During the reign of Duke Magnus (the younger brother of Frederick II of Denmark) in 1570-1578, Põltsamaa was the capital of the Livonia and the residence of the King of Livonia. References to this fact appear in oral narrative lore, even though in people's minds the symbol of power is a combination of what has been learned at school, media texts, oral narrative history and folklore. For a short period of time after the Second World War, Põltsamaa functioned as an administrative centre of the district, which meant advantages in economic development, higher employment rate and local administrative structures.

The local history of the town is largely similar to the events that took place elsewhere in Estonia, including the great plague epidemics in 1657, the great famine in 1695-1698 and in the 1840s (Viljandimaa 1939). Religious life in Põltsamaa also resembles that of other Estonian regions - the first Christian crusade to Põltsamaa and the ancient Mõhu parish took place in 1212, and was followed by the Christianisation of the local population in 1220 and, naturally, the building of the church which was first mentioned in documents in 1234 . In the 16 th century the population converted to Lutheranism under the influence of the upper 
class. 1846 marked the establishment of the Orthodox congregation with a considerable number of adherents. The central constructions of the town - the church, the stronghold (dating back to 1272) and the castle, which was constructed later - have been repeatedly destroyed in plundering raids and wars. Most of the town was destroyed in 1502, and during 1562-1582, and later, of course, in 1703, during the Great Northern War, when many Estonian tows were burned down by the army of Peter the Great. In the 1944 bombing of the Second World War 75\% of the town (private houses) were destroyed.

The church of Põltsamaa burnt down in 1600 during the PolishSwedish war, and, again, on July 14, 1941. After the first great fire it took thirty years to rebuild the church, after the second burning, the church was rebuilt over ten post-war years in the mid-Soviet period by the legendary charismatic pastor Herbert Kuurme (further on this see Kuurme 2001b). Herbert Kuurme has presented the considerations set forth during the latter reconstruction of the church in his diary comments and official documents. Originally, the church was to be built on an altogether new spot:

It was emphasised that the church should not be moved, but should remain where it was once erected, as the Word upon which it was established is also permanent. In many places the first Christian churches were built even on the sites of ancient Estonian sacred groves. Still, many faults were found with the former site of the Pôltsamaa church. Heating the narrow and high space used to be problematic, since the air moves up. The organist's room was located under the church tower, muffling the softer sounds of the organ. There was not enough space for the church choir. And, also, the church-goers had no place to leave their horses to, and had to use the yard of the Farmers' Society across the river for that purpose. The moat limited the space around the church. Furthermore, at the time people well remembered the flogging that took place in the castle yard during the 1905 Revolution. Thus, people unanimously agreed to start constructing the church on a new site (Kuurme 2001a: 207). 
Nevertheless, the church was built on its old site, but the flogging of 1905, a hated and shameful event, was still a topical subject of conversation in my childhood at the beginning of the $1960 \mathrm{~s}$, and was also brought up during the fieldwork in Põltsamaa in 1981. The church was re-inaugurated in 1952, but the construction and renovation works lasted until 1979 (Kuurme 2001b). Among other things, the steeple cockerel that had fallen off the church spire during the war was restored in its place years later. Reconstructing the church definitely united the congregation: it became a common cause shared by the townsfolk and the church minister, a long term cooperation, which resulted in one of the few new churches during the period so unfavourable towards religion (Sychev 2004, Plaat 2004).

During the Soviet times, quite a number of people visited the church; in the 1950s and 1960s, confirmation classes were attended by many and the processions of children receiving confirmation was a memorable event. The church minister was well respected among the townsfolk, and used to send handwritten birthday cards to the members of his congregation. The network even exceeded the limits of the congregation, as the minister held brilliant sermons, and was a man of considerable reading, whose Sunday sermons delivered in the 1970s included discussions about the philosophy of, for example, Albert Schweitzer and Mahatma Gandhi, but also poetry and political argumentation. He was remarkable in his sincere emotional empathy with the happiness and sorrow of the personal life events of his congregation members during the sermons. His tears and delight in the pulpit, his good knowledge of the world events and youthful nature were truly impressive. All the above is not intended as an encomium to a fine Lutheran minister, but serves to confirm that even in the worst of times, the church remained a place for spiritual awakening.

Since the 17th century, Põltsamaa has repeatedly occupied the central position in the master narrative of the independent Republic of Estonia and its cultural history, owing to the prominent figures who have lived there, innovative ideas and modernisation, active social life but also stability: the song choir established in 1840 and a brass band, which first came together in 
1856, are still the symbols of the town. Their repertoire includes the creation of local famous composers, of whom Karl August Hermann's and his famous sister Miina Härma's works belong to the canon of Estonian choir music. Both musical collectives have survived owing to great conductors and strong leaders. In addition to good peasant schools in the region, church minister A. W. Hupel and the head of the medical school P. E. Wilde started to issue the first Estonian-language magazine Lühhike öppetus... ('Short Introduction...' 1774). During this period the town had a working pharmacist, a hospital, a printing house, and a school. A. W. Hupel also organised a reading group in the town, and published his Topographische Nachrichten von Lief- und Ehstland IIII (1774-1782), which is used as a reference source even in modern academic research, as well as Nordische Miscellanen (1789), and also studies of the main dialects of the Estonian language.

As to the 19th century, the period of characteristically active and expanding social life in Estonia, I should mention one of the central national projects of the time - namely, the idea of founding the Estonian Alexander School, the first Estonian-language school of higher education, which was to be established in Kaarlimõisa in the vicinity of Põltsamaa with the contributions from the general public. The intensification of Russianisation policy, however, interfered with the plan: the school was opened in Kaarlimõisa but as a Russian-language school, and could start providing education in the Estonian language only in the early 20th century when it became one of many similar Estonian-language schools. In the second half of the 19th century, the local school became the hotbed of national awakening, where future Estonian composers, historians, writers, scientists like Karl August Hermann, Jaan Bergmann, Jaan Jung, Mihkel Jürmann, Martin Wilberg, Aleksander Mohrfeldt, Eduard Bornhöhe, and others taught and studied. The historical novel Tasuja ('Redeemer') written by young Eduard Bornhöhe in Põltsamaa is included among the classical Estonian literature about the Estonian fight for freedom. One of his novels has inspired a hugely popular adventure film Viimne reliikvia, or "The Last of the Relics', the first so-called Soviet "western", which became a cult movie in Estonia and which popularity has, in turn, inspired innumerable quips and parodies in Estonian folklore. (The intellec- 
tual culture of this and earlier periods has been thoroughly studied, see e.g. Aru 2004, Viljandimaa 1939).

Let me also mention that Põltsamaa is closely connected with the Estonian national flag - it is here where the members of the Estonian Students' Society (established in 1870, and active until now) argued about the colours of the future flag of the society, for which schoolmaster Gustav Heinrich Beermann had suggested a tricolour of blue as a symbol of loyalty, black as a symbol of earnestness, and white as a symbol of purity. This was to be the flag for the first society of Estonian students, established to counterbalance the German(-language) fraternities in Estonia. This very tricolour became the flag of the independent Republic of Estonia.

The general standard of life in the 1930s was good. By the 1950s the social and intellectual sphere and the number of entertainment facilities had decreased, the general economical situation was rather bad. The historical aspect mentioned here is something that most locals take pride in. However, the symbolic meaning of Bornhöhe's book Tasuja, the first magazine, the local prominent figures in cultural history and science, the connection with the Estonian Students' Society and the national flag of the Republic of Estonia, several economic and technical achievements, is definitely highly abstract and cannot be separated from the national master story. Herman Davis has said that modelling, and enabling others to model, is an emergent constellation of spatially related entities and creating the cognitive maps, which can represent worlds in various degrees of detail and precision (Herman 1999). I suppose that the best way to describe the postwar situation in Põltsamaa is remembering the acquired honour. Halvor Moxnes (1997) concludes that honour is fundamentally the public recognition of one's social standing. It comes in one of two ways. One's basic honour level, usually termed ascribed honour, is congenital. Each child takes on the general honour status that the family possesses in the eyes of the larger group, and therefore ascribed honour comes directly from family membership. It is not based on something the individual has done. By contrast, honour conferred on the basis of virtuous deeds is called acquired honour. Acquired honour, by its very nature, may be ei- 
ther gained or lost in the perpetual struggle for public recognition.

\section{Honour, Shame and Other Emotions}

Research on the role of emotions and their regulative function in morality has received considerable attention in psychology during the past decade. It has been argued that since 1905 shame has been ignored or little mentioned in orthodox formulations, since Sigmund Freud has noted that in modern society shame has become to be associated with children and guilt with adults. Many authors, occasionally also anthropologists, have relied on this postulate, and have neglected the study of this important phenomenon for decades. Similar views are also introduced in several recent studies: Rhoda Howard (1995), for example, proposes that male domination and racism increase the likelihood that women and blacks will experience shame. She suggests that they are dishonoured, and their status is consistently derogated. To coordinate their actions in a white male-dominated society, women and blacks must take the role of white males. I will return to this argument shortly.

Another popular view is represented by Thomas Scheff (1991) who argues that although shame may be the master emotion of everyday life, it is usually invisible in modern societies because of taboo. Evidence for a taboo is suggested by a review of shame studies. The work that concerns shame has been largely ignored although it implies a vital connection between shame and social life: shame can be seen as a signal of threat to the bond and would be necessary for the study of social systems.

In the 20th century, the concept of shame and honour has often been studied from the aspect of the Bible (cf Moxnes 1997, Neyrey 2000) and specific written documents. These concepts have deeply rooted in stereotyping, and carry a specific meaning. Honour and shame have been considered most characteristic of classical and medieval European culture, where these concepts were used as criteria for, say, punishment, and where the loss of honour may have equalled, in some cases, even with a person's social death. The concept of honour was closely interrelated with rules of behaviour, gender and social status. Honour was usually lost by 
marrying down, outside the caste, marrying a dishonourable, poor, etc. woman. A person who fell in shame as a result of such behaviour lost his social position, all privileges, social network, and may have even lost his life. Numerous modern British novels indicate that the same system operates also in the modern era. As to Estonia, a true life story about Barbara von Tisenhusen, who fell in love and married a simple bourgeois writer, is known from the 16th century. With her conduct she had violated the "law of Pärnu", which prohibited, under the threat of death, upper-class women to marry bourgeois men. Barbara's brothers, who had fell into dishonour by her actions, drowned her into an ice-hole. Analogous motifs have inspired newer folk songs - for example, the young Saare Countess narrates about the estate owner's daughter's love affair with a young farmer living across the lake. The desperate lady drowned herself. Similar ballads belonged to the repertoire of nineteenth-century village songs, but were also known in oral narrative lore. Oral narrative history, largely enkindled by literature and tourist industry, also includes a legend about a knight who as a punishment for his wrongdoing was walled in a room in the castle of Saaremaa, which was built of dolomite rocks in the second half of the 14th century and is well preserved even today.

Social anthropologists have taken special interest in the Mediterranean and South-Eastern countries, which have been associated with well-preserved and deeply rooted traditional concepts of shame and honour, closely related with gender markers. As a rule, shame has been associated with women and their conduct, whereas honour has been generally associated with men as it was common in medieval times. The same system, the same pattern seems to apply in an even wider area - in Armenia and Georgia, for example, these concepts are present also in contemporary stereotypes and behaviour.

Over the past few decades, psychologists have viewed shame as a vital emotion, which may function as a strong motivator in studying, especially for women and the older generation (Butcher 2004), and have also studied shame as a many-sided emotion which has had a deep influence on autobiography and culture (Dalziell 1999). For example Rosamund Dalziell has pointed out patterns of shame, which appear to operate, with variations, in the Estonian con- 
text: such categories are, for example, superiority of another culture and shame associated with race, national identity and immigrant status that intensified in the period following the Second World War.

In psychology much relevant work concerns the role of moral emotions in moral behaviour (Eisenberg 2000: 665). As to basic emotions, we know the sources from which they arise, the different forms they may take, and some of their outcomes. Research on differences between emotions like fear, anxiety, embarrassment, guilt, and shame and their relations to moral behaviour are investigated as well as regulation of these emotions. Helen Lewis has argued that most states of shame are not consciously experienced, but are either unconscious or undifferentiated or bypassed (Lewis 1971). She suggested that shame used to be a dominant force, the master emotion because it has more functions than other emotions. In analysing shame episodes, Lewis identified a specific context of shame: situations, in which the patient seemed to feel distant from, rejected, criticized, or exposed by the therapist, generated shame markers. She realised that shame arises from seeing one's self negatively from the point of view of the other. However, patients showed two different, seemingly opposite responses in the shame context. In one, the patient seemed to be suffering psychological pain, but failed to identify it as shame. This form she called the overt, undifferentiated shame. In a second kind of response, the patient seemed not to be in pain, revealing an emotional response only by rapid, obsessional speech on topics that seemed slightly removed from the dialogue. She found that anger markers in the patient's speech were always preceded by shame markers. Apparently one way of hiding shame is to become angry. Other feelings resulting from shame are the need to hide oneself, disappear, the sensation of sharp pain, discomfort, the sense of worthlessness, incompetence, inaptitude and the mergence of object and subject.

Also, H. Lewis and T. Scheff defined shame socially and broadly as all effects that arise represent a threat to the bond which is narrowed in the modern treatment of shame and used to be broader in traditional societies. Shame is a component of moral sense, much like anger is a signal of frustration. At the same time fear is a signal of danger to the body. 
Shame is believed to be a form of superego functioning that may regulate human behaviour (Lewis 1971). But the question lies within the social self and one's self-perception, the aspects of self that one wishes to reveal, or, to the contrary, hide. Michael Lewis defined shame as a mark or characteristic that distinguishes a person as being deviant, flawed, limited, spoiled or generally undesirable:

What is an exposed self and to whom it is exposed? The self is exposed to itself, that is, we are capable of viewing ourselves. The subjective and objective selves are differentiated. The objective self can reflect on and reject any solution generated by the subjective process. The objective self uses metaphors; the subjective self operates with a simple sign systems. The objective self allows us to stand back from our own processing and thereby increases the possibility of generating new solutions (Lewis 1992: 36).

In general, stigma signals a failure to meet societal standards, rules, or goals and this may subsequently result in social isolation or be a threat to social bonds (Scheff 1997).

Jenkins' model provides a theoretical base for shame that charts its attribution through the dialectal interplay of internal and external forces that are integral to experience (Jenkins 1996). As to the horror tales under discussion I was more interested in the results concerning the expression of shame and other emotions by people of different age groups and different gender, as it has been argued that gender seems to play an important role in the intensity and frequency of moral affective experiences (Lutwak et al. 1998). It is a common stereotype that women are more likely to experience empathy and guilt while also engaging in more prosocial/reparative behaviours than men. Psychologists Jacqueline B. Panish, Brian E. Razzino and Joseph R. Ferrari argued that compared to men, young women reported significantly greater levels of shame and guilt. Among women anger expressed inward was associated with shame-proneness, while increased inward anger and a decline in anger control were associated with shame-proneness among men. While expressions of hostility and anger appear to be related to moral affects for both genders in late adolescence, and future success expectancy 
to be relevant only for young women, these variables seem to have special significance in the guilt and shame experiences of young women and men. Partial correlations also indicated fewer outward expressions and greater control of anger to be associated with guilt-proneness for both men and women. However, in 2001, Thomas Scheff concludes on the commonly agreed view of shame being implicated by the production of social control and conformity that it may be that feelings of tension and guilt among women may work to control and diminish anger expressions. Ervin Goffman, who is considered among the classical authors, suggests that the risk of stigmatisation is present within the most routine or banal social occasions in that there is no interaction in which the participants do not take a chance of being slightly embarrassed or a slight chance of being deeply humiliated (Goffman 1969: 215).

\section{Places of communication and modes of communication}

Let us now return to the topic of the small Estonian town, about which could be said that "[t]here was nothing missing there, except the State" (Kelly 2004: 65), a quotation that characterises its life better than any other description. The war was lost and oral narratives were tales about losers, even though officially Estonia was, by mediation of its pre-war puppet government, seemingly among the victorious countries. The situation of those who lose a war or have no say in many important issues determines not only their attitudes and behaviour but also story-telling strategies. In many families, topics concerning the events before and after the war were rarely discussed publicly and in the company of children. Regardless of that I have decided to limit the choice of material to my own recollections and information obtained from fieldwork interviews.

The town lost nearly third of its population in the period before, during and after the Second World War incl. 78 persons during the Russian deportations in March 1949 and more than 300 persons in June 1941. In the mid-1950s the town was rebuilt and displayed almost no signs of the past war. Põltsamaa was a culturally active small town, which was characterised by private residential houses, a library which had miraculously survived 
since the previous period of independence, and active social life. The idyllic and peaceful town scene acquires a new context if we consider that during the 1944 bombing was targeted at residential houses, and the electric power station, industrial facilities and manor buildings, i.e. facilities necessary for economic activities, were left intact.

According to the Louis Botella, people do not construe a world totally on their own, neither are they totally confined to social expectations about them. The relationship between what might be called personal and social constructs is likely to be a dialectical one, in which the person adapts his or her self-theory or selfnarrative to social feedback and, at the same time, selects what will count as relevant feedback. Self-identity, self-narratives are validated or invalidated by means of the social context in which they take place (Botella 1994). The typical places for communication in the late 1950s were evening schools and hobby groups, horse stables (later car stations), the church, cemetery, and family gatherings.

In the $1950 \mathrm{~s}$, the period following the Stalin's regime, a few evening handicraft, cooking, and language groups were active in Põltsamaa. These groups were the places where women mostly gathered. My mother used to visit one of such groups after work and as she could not leave me elsewhere I was among the few children who were taken along. For me these evenings used to be very long and even scary, in a sense. While doing handiwork women talked about everyday incidents, true stories and rumours, they made jokes, though I can't remember them ever singing. Many stories were told that had happened in the northern part of the country, which was a mining region, where new settlements were established and where numerous new Russian immigrants arrived. Most of them arrived with referrals from Russia (resettlement was strictly controlled but it was considerably easier to get immigration permits and referral letters for the socalled "construction and shock work territories").

Men from our neighbourhood (at that time we lived in an area adjacent to the castle, church and a former manor house) used to gather at the horse stable, including men who did not work with horses. As it was a former manor stable, it was called a 
manor and a manor stable, even though half a century after the nationalisation of manors in 1918 there was no particular reason to call the place by that name. It was a main story-telling place for men, and children were allowed to be present, too.

In this town the time for tidying the graves (before major festivities people habitually visited the graves of their relatives) and commemoration days at cemetery was on St. John's Eve. At major church festivities, especially during church ceremonies people took time to share news about relatives and friends. Often the conversation continued at someone's home.

The main places for exchanging information were family gatherings, important events, weddings, funerals, and somewhat less so birthday parties, where relatives, often also distant and marginally related people, gathered. At these events they sang, played instruments and folk games, and told stories, constructing stereotypes and attitudes. It was the most important place for presenting oral history. Communication style at these parties was presumably shaped by local communication type and habits. It is a common knowledge that in many areas some topics (personal life problems, intimate or embarrassing issues) are generally not talked about in wider circles; peculiarly, though, current politics was a popular and acceptable subject of conversation. Kinship ties prevented criticism or politically dangerous information from falling into the hands of wrong persons. (Actually stories were told at workplaces, in cafés, in shops, on fields of collective farms and at social gatherings, too. Thus the storyteller had to feel safe in his/her social environment or group.) A part of information was diplomatically complicated, such as, for example, messages about relatives and their life abroad, looking for missing people, memories from the former independent Republic of Estonia and people's former economical situation. The contradiction between public and private information became to be known very clearly oral and unofficial information, as well as imagination, became the source of all the missing details. I still remember visits to my relatives who read out letters from relatives who had emigrated to the USA and Canada, and showed fancy things sent from there.

Many political topics were censured from public information, the past and cultural history was rewritten. This meant that in peo- 
ple's homes there were many photos, letters and printed matter that - like oral lore - told quite different facts than at schools or spread over mass media. It was not before the 1960s, when literary history in Estonia began to acknowledge major emigrated authors and they were included in school curricula. While oral lore is easy to underestimate or invalidate, the veracity of printed matter is psychologically more difficult to overlook. One cannot disregard the message they convey.

Migration, return of former deportees, letters and information from abroad, Voice of America and rumours became the major sources for communication and folklore. In 1955-1956, the deported Estonians had been released from concentration camps in Siberia and had returned to their homes with their experiences, memories and narratives. To illustrate the spread of information at that time I will give only one example. Among my mother's friends there were two sisters who had survived the Leningrad blockade. Tamaara and her sister Valja arrived in Estonia after the war. They belonged among the so-called St. Petersburg Estonians, whose parents were deported to Siberia by the Stalinist regime in 1933. I remember long walks with my mother and two sisters up and down the street and sometimes all the way up to the vegetable gardens in the outskirts of the town. Their stories told about people eating cats and dogs, the endless hunger, cannibalism, mysterious disappearances. Telling stories served as kind of psychotherapeutic sessions (Howard 1991: 191) for sisters, the posttraumatic reaction. For a child, all this belonged to the fancy stories that most other adult women told each other.

Fragmentary information about the spheres of criminality, medicine, geography caused rumours and jokes. Geographical borders indicated that all maps were imprecise in order to limit the information available for possible enemy espionage. Official rhetoric and information publicised by medical and police circles declared that firstly, the Soviet medicine could cope with any disease, epidemics were liquidated after having conquered poliomyelitis, and secondly, criminality was generally nonexistent. Few had to be re-educated and some criminals were arrested for spending public money or misusing public property but such cases were rare. Therefore, apparently there were no thieves or mur- 
derers in the Soviet Union. Oral lore confirmed that the media and the police were not allowed to publish the actual information or to show non-Estonians as criminals, drunks or hooligans. This area has also produced much oral lore and anecdotes.

Traumatic tales were recurrently revived by people who had returned from concentration camps or migrated from the areas of hunger. The themes of the tales, however, had changed considerably - next to progressive tales, people had started to tell the sc. regressive tales (Gergen 2000) - tales of woe in soliciting attention, sympathy, and intimacy. Analogously to other Estonian regions, oral communication here was not divided merely into private and public, but was founded on reciprocal trust and guarantees of social networks. Many topics, however, were discussed only in the company of adults, and were not shared with children.

\section{Sausage factories and fatal relationships}

It is quite impossible to reconstruct the real contents of stories, or restore the whole context of presentations. Horror tales and fears range from non-fiction to fiction proper. Many motives and story-chains have been caused by the lack of information, fragmented relationships, destroyed social structure, changes in everyday life, and different kind of fears. Fear can also be experienced through absorption of threatening information. Psychological research has demonstrated that fear can be acquired either through a conditioning process or by vicarious experiences. The latter ones are believed to be developed by observing fear in others which seems to be quite an important aspect in the spread of horror stories. If we were to put together a list of fears that can be found in these tales, it would include the fear about existence, crime, concentration camps and prison, war, sanctions for political dissidence or for behaviour interpreted as such, the Soviet police system and KGB, racism based on ethnicity or the past, institutionalisation in the mental hospital, as well as the totally rational fears against technical innovations, strangers, etc. A considerable part of the fears were associated with the established Soviet regime and the way it actually functioned. 
I will present only a few examples of the rich Soviet narrative repertoire, before addressing the gloomy stories closely interrelated with reality.

Among the subcategory of different kinds of political rumours, we can also encounter stories about unusual techniques. Laconic and misinterpreted information and political pressure were often the cause of new narrative motifs. Such as, for example, the head of Stalin being cut off before his death and conserved. Exactly on the right moment, it will be reconnected with a new biological body and he would regain the power. Another tale spoke about a man walking around in the Kremlin in Moscow, who is made of iron, filled with uranium and who would explode any moment. The next explosion would destroy the entire Europe.

Fears can be generated by information that is slightly or not at all threatening but which is misinterpreted by the recipient as being threatening (Rachman 1990: 192). After the Second World War there were very few contacts with peoples and cultures outside Estonia, but there were cautionary tales about cultural conflicts, tales concerning misunderstandings connected with different behavioural norms in cross-cultural communication. For example, stories warned blond women from travelling to south, also there were rumours about what may happen to the tourists in the southern states of the Soviet Union. Robbing women was a very common theme, namely, that men in the area are in the habit of robbing white (resp. Estonian) women and bringing them to their harems. The legends were quite detailed, mentioning also persons and places where it supposedly happened. The stories warned that by looking in the eyes of a prospective capturer and smiling, a woman gives a message that she agrees to become robbed. The robbed woman, of course, can never come back because she will be sold to a harem somewhere in the mountains and watched after. Only few of the captured women have been able to escape. Similar stories were told about Africa. After the Second World War seeing a black man in Tallinn was unthinkable, except for the students of the maritime school where young men came to study from the states favoured by the Soviet Union. Much rumour was provoked by one young local woman's marriage to a black man and her settling in Africa. It also revived earlier urban legends about other cultures. 
Research into fear of crime has grown substantially in the recent years, suggesting that the fear of crime is a topical social problem. The same conclusion can be arrived by comparing the atmosphere in the period following the Second World War and that of the 1950s and 1960s. Around that time there circulated a very wide-spread story about a girl from Kohtla-Järve who disappeared and whose death inspired rumours and cautionary tales. The girl was found murdered in the forest, circumstances of her death remained unresolved and as there was no public information about it, the lore was lively and abundant. Mostly Russian speaking workers were accused of her death. It is noteworthy that folkloric tales about this incident were sent even for the 1992 campaign for collecting school lore, suggesting that the impact of such incidents were indeed profound.

Among the narratives of the period following the Second World War, the most complicated ones are those connected with true experience and strong emotions, stereotypes and fixed attitudes. The verisimilitude of these stories is rarely questioned, since they contain truthful situational details, and conform to the narrator's worldview and expectations. In narratives of this main pattern, the real history is embedded with fiction. On the border of oral narrative history, personal experience tales, urban legends and rumours there are post-war stories about making a sausage of horse or human meat and the black cars of bloodtakers. The stories about blood-takers and sausage factories were in these days very feared, narrators and audience took them seriously.

The lore about black cars is based on reality, as the Soviet police used black cars called Chornyi Voron or 'the Black Raven' all over the Soviet Union, including Estonia. In Russia, arrests, interrogations and nightly deportations in Black Ravens started after the October Revolution in 1917, but escalated during the 1930s and after the Second World War. The Estonians' contact with the black police cars and trucks used for deportations started in the 1940s after the Communist coup, continued in the Soviet home front and after the war and reached the culmination in 1949. Let me present some fragments of people's recollections about these: 
Elmar Ala (residing in Maarja, Jõgeva County) reminisces about the UAZ truck in the labour camp no. 861: "Three young men from the Võru County (can't remember their names) ran away from the labour camp. They had been missing for days before they were captured. One morning we were all lined up in two rows, and the Black Raven drove in between the rows. The three fugitives were told to get out of the car and were shot on the spot." (Usai 1993 a, b; http://www.okupatsioon.ee/ kaastood/kondoja/meenutusi.html)

The Black Ravens (black cars of Soviet origin) were spying day and night, taking the victims either before the court-martial, to the Kawe cellar ${ }^{1}$, or directly to the freight wagon deporting to Siberia. The court-martial trial usually concluded with passing a death sentence. The Black Raven which appeared at the gate of the Mäe farm in Limu village at broad daylight was unable to turn in the narrow stone wall gate. Kusta was tidying the flour bin in the granary with his sister Selma. Wearing an apron and a headscarf and covered with flour, Kusta looked just like his sister Selma on the granary door. When the enemy soldiers asked after Kusta Põldmä, his sister Selma told them that he wasn't at home. They looked through all the other buildings and left with empty hands. From this point on, Kusta led the life of "forest brothers" (Estonian partisans who hid themselves in the woods to escape deportation) (Sagris 2002).

Or a comment to the activities of a radical youth organisation of Tartu around the October Revolution festivities in 1949:

Let's not confuse the present day with the year 1949! For those who do not remember these days back then... there were the March deportations, a Black Raven driving along the streets at night, taking Estonians from their beds to the cellars of the Grey House ${ }^{2}$... (Päärt 2004, commentary by Vanaätt 05.11.2004, 11:14)

Let us return to the latest results in trauma research by psychologists, who have argued that such tales and the self-position presented in these tend to change in times, but the most important facts remain. After Tuval-Mashiach, et al (2004): 
It would seem that the period immediately following a traumatic event is when the most intensive processing of that event takes place, at a narrative and a cognitive level. At this time, there is not yet a coherent organized story with significance this takes place in the weeks following the event. During this time, the story changes and grows, and various factors influence this process, including new information, circumstances surrounding the event, perception of the trauma and subsequent symptoms, and the cultural context in which the survivor lives.

As to the black cars and blood-takers, these tales are spread not only in Estonia but, like the sausage factory tales, elsewhere in the Soviet Union and Eastern Europe, also in Germany and Finland. At the 1987 Soviet conference of children's lore, the delegates of other Soviet republics (among others a folklorist from Kazakhstan) proved to be familiar with these stories as well. These stories were believed to be based on real life events. The same has been confirmed, for example, among the Germans. In both countries, the oral tales relied on actual court trials. In 1937, fabricated show court trials about former party leaders, but also doctors, geneticists, military functionaries, experts, middle managers, the intelligentsia, who were accused of damages, hostile activities, poisoning, political crimes, were held in the Soviet Union. Frank Galioti (1996) describes: The year 1937 saw widespread arrests of geneticists who were now referred to as "Trotskyite agents of international fascism". Incidentally, this was a continuance to the accusations of the members of the intelligentsia, a motive for their arrest and execution; the same accusations concerned the Jews. According to common beliefs such rumours were initiated by security agencies, including tales about the Jews and scientists who conduct human experiments, i.e. collected blood. Articles published in the written press definitely had their impact. In Estonia such tales were documented mostly in the period following the world war.

The extent of such fears can be concluded from the accounts contributed to the folklore archives by local correspondents:

In June 1965, a topical story was circulating, telling that the Jews drove around in cars, asked younger people and those of 
heavier build to step in the car, rendered them unconscious, pumped their blood out and threw the bodies in the woods, then sold the blood to hospitals where blood transfers are made. The old warned younger family members from approaching any car at the call of someone they didn't know. If people who were more aware explained that no hospital bought blood in this way, another explanation was found: they smear keyholes with the blood of Christians.

A valuable aspect of this recording is that it documents the period, it has been written and sent in the archives at the very time of the tales' circulation. Several discussed beliefs and interpretations are truly noteworthy, such as, for example, the forcible collection of donor blood (which was indeed feared, because according to popular beliefs, donating blood damaged health, caused obesity and tumours). While the motif of dumping the dead bodies after executions to the bushes was rather common, the Jews are rarely talked about in the Estonian lore, though various antisemitic motifs mostly migrated here together with the mass immigration of hte Russiophone population in the period following the Second World War. It is possible that the use of Christians' blood belongs among the new migrational motifs. Even though many motifs of international narrative lore have been associated with Jews, they had few ground in Estonia. Jews were granted the right to enter the region by a statute of Tsar Alexander II in 1865. The local population was small, centring mostly in towns. The marginal contacts with them did not inspire rich local folklore (see Laineste 2005: 42, Loorits 1955). The Jews constituted a mean $0.4 \%$ of the Estonian population, making up 4,434 inhabitants in 1934 and 5,436 inhabitants in 1959. After the Second World War Estonia was the place where reputed Jewish scholars, musicians, artists settled or came to study.

The extent of fear against donating and collecting blood decades after the end of the war is illustrated by the words of another informant:

A woman told me how she saw a car and two men at the road. One of them was holding a square box with a half a meter long tube hanging out of it. She thought that they were blood collectors, started to speed up on a bicycle as fast as she could, 
trembling over all her body. Afterwards she learnt that those men wanted to take a juice sample from the linden and elm. (RKM II 221, 406/7 (2) < Häädemeeste parish - Marta Mäesalu (1965).

Reality and imagination intertwined in much feared tales about sausages made of horse meat. Horse meat is generally regarded as highly unusual and abominable food in Estonia. This cultural stereotype has even been so unacceptable that even the most cruel stories about manor landlords do not accuse them of eating horse meat, although they are generally accused of virtually any thinkable impropriety. The stories about horse meat factories were fed by the fact that old or injured horses were taken to furriery. Among other rumours there emerged the transference that the Russians make sausage out of horse meat to keep secret the deficiency of meat, and which actually is included in their cuisine. Here I will not address another stereotype strongly associated with this nation, which constitutes a very extensive field of study. Fictitious sausage factory tales were particularly frightening and topical in the 1950s and 1960s, even though similar narrative tradition has been known a century before and later (Kõiva 1997). Regardless of the attempts by media and veterinaries to stop the spread of rumours, the folklore about abandoned ruins and sausage factories continued to spread for years, and this was instilled deep in the memory of people. The most recent campaigns of collecting life stories have resulted in recollections about this tale, still shrouded by deep-rooted beliefs in the reality of events and fear.

These stories are very simple: a random walker is cheated into a sausage factory or its neighbourhood from where he or she miraculously escapes. In many cases, the location of the factory is a particular town or a part of town, mostly Tartu (or Tallinn), which is left in ruins. On the one hand we encounter the same symbols and fears that applied to the ruins in the 19th century, and on the other hand these were truly dangerous places, where homeless people lived and where dangerous explosives were found. The presentation is often very intriguing: the events are described as a homodiegetic personal experience story by both men and women. Even at an advanced age, people confidently pass on the story to children or acquaintances as something that has hap- 
pened to them personally (further on this see Kõiva 1997 and 1998 , children very rarely use first person in analogical narratives). The story can be presented in a way that the narrator is recognised for having successfully overcome a complicated situation, rather than appearing as someone who has been disgracefully tricked or manipulated.

Let us consider another group of tales characteristic of the period that could be tentatively referred to as tales of fatal relationship. The basic motifs that have been recorded in greater number told about the relationships between men and women. A special cycle was formed by the stories of wild women who tried to please their lovers by murdering their children. In one of them a women tried to please a man and the man agreed to marry her only if she murdered her child, and she fed the child poison. The child fell asleep; the woman put him into a coffin and buried him in the garden behind the house. The man married the woman but the story became known. It became known because someone living in the neighbourhood had been digging the earth at the same spot for some mysterious reason and had found a coffin. The child was dead. In another version, a woman poisons her children with candies at the demand of her lover and tries to bury them secretly. In some variants, the child could be resuscitated and a random passer-by dug the grave open upon having heard a voice. The story remained unknown but the lover left the woman and the woman herself let the story to be known.

This reminds the familiar fantasy story where the man agrees to marry if the woman proves her love by boiling her child. The woman resists but finally she has nothing left to do but kill the infant, boil him and serve it to her lover. The lover (claiming that he had been joking) leaves the woman on that account. Quite a similar variant tells about a woman who used to beat her children every evening at the demand of her lover, and the neighbours rescued the children by letting them live in their home.

The most popular story spoke about a man who was driving along the road through a thick forest. All of a sudden he heard a strange voice in the forest, stopped the car, went to look between the trees and after a long quest, found a naked child tied to the tree. The child was weak and badly bitten by flies and mosquitoes. The 
driver untied him and asked the child what happened. The boy said that his mother and uncle (lover, or his mother's new husband) persuaded him to go to the forest, told him to take off his clothes, tied him to the tree and left him. The driver took the child to his car, wrapped him in a blanket and gave him food. Having driven for a while they saw two people walking along the road. The child recognized his mother and that man. The driver hid the child behind the seat and asked him to keep quiet. The mother and her lover hitchhiked and asked to be driven to the closest town. They had been taking a walk in the forest. The driver let them in the car and drove straight to the police station. The mother and the man denied what they had done but the driver brought the child out and having evidence of this weight, the mother and her lover were forced to confess the truth. They were imprisoned for life.

These tales were told at the evening handicraft groups, and none have been presented as first person stories or as events that have happened to a more distant acquaintance. What was it that made people present these tales in the second half of the $20^{\text {th }}$ century as true stories? These simplistic tales have equivalents in fiction, ranging from fairy tales, where the (cannibal) husband demands that his wife made him a meal of her child, or where cruel sisters-in-law wish to get rid of a young girl, to the $19^{\text {th }}$ century pious literature, which, among other sufferings, told about execution of children. The tellers and listeners of these tales had certainly heard several of these tales, or, perhaps the tales of canonical Latvian author Ancelane.

Behind the story there is often a subconscious reaction to frustrating situations, strange cultures and national groups, or total instability. In such context, some old motifs were probably revived with the help of oral communication and analogous fiction. I am quite convinced that in the 1950s and later, during the evening handicraft groups that brought together young unmarried or married women, mothers up to the age of 35, served another important function of marking the changes in family model and behavioural norms, and reflected certain tensions in the society. The changes had started already in the 1930s, when the war and the post-war period intensified these tendencies. There were many single mothers and divorced single women 
among them. Even if a woman lived with her parents or those of her husband, establishing a new relationship was inevitability rather than exception. Simple tales represent a more conservative worldview and function as if cautionary tales, tales where people test their own limits but serve as a resistance of a conservative system to the changing situation. These tales were probably inspired by analogous reason than that of travel stories mentioned above - one could not avoid travelling, but at least he or she was warned. However, there is one characteristic feature that prevents these tales from being egomorphic - namely, the collective concept of honour and shame, which prevents the narrators from identifying the tales with themselves or people they know.

According to Kenneth J. Gergen:

Narratives of the self are used within daily life as a means of creating or sustaining value - the value of both oneself and all other protagonists who feature in the quotidian tellings of a life. In the case of self, the value generating function may be linked in particular to what may be called "moral identity," one's definition as a worthy and acceptable individual by the standards inhering in one's relationships (Gergen 2000).

\section{Conclusion}

This paper is an attempt to observe on the basis of tales spread within a limited timeframe and in a limited environment whether abstract stereotypes and emotions, as well as changes in the social situation have been reflected in the contents of these tales. I have observed pre-war and postwar monoethnic instances on the example of a particular town (including some interviews with Ingrian-Finnish families), how and which fears were spread and what made people feel shame. These are certainly only fragments of the general tendencies, and I am positive that only a knowledgeable collection of manifestations of stereotypes and prejudices helps to explain various patterns of behaviour and narratives. Choosing this town was determined by its peaceful milieu without major construction works and criminal activities, also by prominent local figures (here represented by the church minister) and the following of family traditions, which preserved con- 
sistency in narratives, traditions, and linked to the more distant past and oral narrative history. An important and characteristic feature of these tales was pride about the past, which were overwhelmed by the tides of the period. People fled from deportations from this town, too, and in the rest of Estonia, narrative lore was about the same than in this relatively safe town. In the $1950 \mathrm{~s}$, earlier events became more topical: the deportations of 1949, political atmosphere prior and subsequent to Stalin's death, the return of the deportees and people held in concentration camps and their children in the mid-1950s, the events of 1958 in the Eastern Block generated a new wave of fears and horror stories. The repertoire of the stories changed and many earlier stories became topical. The censored media inevitably necessitated the filling of voids in information with lore stories and beliefs: ultimately, criminality was seen in everyday life, oral messages about animal plagues that broke out in the neighbouring countries spread and people were warned of diseases.

People are generally not socialised through trauma or incidents of horror, but they do go through a socialisation process in the event of shame, honour and guilt, in their family, at school or in the nearest group, and through this process they acquire the accepted modes of behaviour and perhaps also patterns to verbalise such situations, or suppress these. Jenkins (1996) mentioned that individual identity is not meaningful in isolation from the social world of other people. Individuals are unique and variable, but selfhood is socially constructed: in the process of primary and subsequent socialisation, and in the ongoing process of social interaction within which individuals define and redefine themselves and others throughout their lives. Moral concepts and norms, no doubt, affect storytelling, particularly their turning into self-presentation. Many tales probably convey values and attitudes that the storyteller has not planned to convey rationally or consciously. I have indicated that children's horror tales basically unveil the primitive fears of abandonment, but also the fear of older people, treacherous parents or adults in general, and various other emotions that the storyteller might not be aware of. The tales are rather associated with other emotions, intended to frighten or startle the listener. The same is true about narratives of grown-ups. 
Specific characteristics can be attributed to tales associated with fear and shame. These stories represent simple goals and they serve moral purposes. They are acceptable because crime will be punished and secrets will be unveiled. The events are typically arranged in linear order and have culmination. The stories' characters are usually attributed a coherent identity and are causally linked to the moral conclusion.

Differential control over narrative content, genre, timing, and recipient is central in the constitution of social hierarchies. Narrative practices reflect and establish a wide range of domestic and community institutions. Differential control over content, genre, timing, and recipiency is also critical to the selves that come to life through narrative (Ochs \& Capps 2001). Many tale plots are widely spread, such as the motifs of sausage factories, blood-takers, and others. An important feature of such stories is a specific historical setting, social relationships and the actual existence of certain ethnic groups and their position in the society. The is no doubt that the principle that Barry Glassner introduces as a characteristic feature of contemporary American society applied also in the 1950s - namely, narrative techniques of fear mongering which are based on repetition, the depiction of isolated incidents as trends, and misdirection, continue in more recent public discourse on actual and potential terrorist attacks (Glassner 2004). Unconsciously, the same methods are used in oral communication.

\section{Comments}

1 The Kawe Cellar a notorious torture and execution place of the People's Commissariat for Internal Affairs (NKVD) on Pärnu mnt. 22 in central Tallinn in 1941. The place was immortalised in oral lore during and after the Second World War by a popular song by the same name. Now the building functions as a museum and historical monument.

2 "The Grey House" in Tartu - the main building of the People's Commissariat for Internal Affairs (NKVD) in 1941. There was a torture chamber in its cellar; the building was a centre of forced deportation at the time, and the location of the Communist Party and the Communist Youth Committee after the Second World War. Presently, "the Grey House" accommodates the KGB prison display of the Tartu City Museum and the rest of the building is reserved for offices. 


\section{References}

Aru, Krista 2004. Ajakirjandusest Põltsamaal (aastatel 1766-1940): ülevaade ja sissepõikeid. [On Journalism in Põltsamaa in 1766-1940: Insights and Overview]. Paar sammukest XXI. Eesti Kirjandusmuuseumi aastaraamat. Tartu: Eesti Kirjandusmuuseum, pp. 57-75.

Butcher, Steven 2004. Giving due consideration to shame - the significance of emotion to adult educational experience. AARE Conference Paper Abstracts. BUT04823. http://www.aare.edu.au/04pap/but04823.pdf

Dalziell, Rosamund 1999. Shameful Autobiographies: Shame in Contemporary Australian Autobiographies and Culture. Melbourne: Melbourne University Press.

Eisenberg, Nancy 2000. Emotion, Regulation, and Moral Development. Annual Review of Psychology, Vol. 51, pp. 665-697.

Gaglioti, Frank 1996. The fate of Soviet genetics. World Socialist Web Site. http://www.wsws.org/articles/1999/feb1999/sov-gen.shtml

Gergen, Kenneth J. 2000. Narrative, Moral Identity and Historical Consciousness: a Social Constructionist Account. http: / /www.swarthmore.edu / SocSci / kgergen 1/web / page.phtml id $=$ manu $\&$ st=manuscripts\& $h f=1$

Glassner, Barry 2000. The Culture of Fear: Why Americans Are Afraid of the Wrong Things. New York: Basic Books.

Glassner, Barry 2004. Narrative techniques of fear mongering. New School for Social Research. Gale Group.

Goffman, Erving 1969. The Presentation of Self in Everyday Life. London: Penguin Press.

Herman, David 1999. Towards a Socionarratology: New Ways of Analyzing Natural-Language Narratives. Herman, David (ed.) Narratologies: New Perspectives on Narrative Analysis. Columbus: Ohio State University Press.

Howard, G. S. 1991. Culture tales: A narrative approach to thinking, cross-cultural psychology, and psychotherapy. American Psychologist, 46, pp. 187-197.

Howard, Rhoda E. 1995. Human Rights and the Search for Community. Boulder: Westview. http://www.hendrickson.com/pdf/chapters/1565632397ch01.pdf

Hupel, August Wilhelm 1789. Nordische Misallancen. Riga.

Hupel, August Wilhelm 1774-1782. Topographische Nachrichten von Lief- und Ehstland. I, II, III. Riga: Johann Friedrich Hartknoch.

Jahn, Manfred 2005. Narratology: A Guide to the Theory of Narrative. English Department, University of Cologne. http://www.uni-koeln.de/ ame02/pppn.htm.

Jenkins, R. 1996. Social Identity. London: Routledge.

Kelly, Michael 2004. The Cultural and Intellectual Rebuilding of the France after the Second World War. New York: Palgrain Macmillan. 
Kõiva, Mare 1997. In A Big Black Town There Was A Big Black House. Journal of the Baltic Institute of Folklore, 2:1, pp. 113-133.

Kõiva, Mare 1998. Human Sausages in Estonia. Foatfale News. Newsletter of the International Society for Contemporary Legend Research, pp. 122-124.

Kuurme, Herbert 2001a. Pildikesi Põltsamaa ajaloost. I. [Scenes from the History of Põltsamaa]. Põltsamaa : Põltsamaa Linnavalitsus.

Kuurme, Herbert 2001b. Pildikesi Põltsamaa ajaloost. II, Kiriku ehitamine. [Scenes from the History of Põltsamaa 2. Building the Church]. Põltsamaa: Põltsamaa Linnavalitsus.

Laineste, Liisi 2005. Tegelased eesti etrnilises huumoris. [Characters in Estonian Ethnic Humor]. Mäetagused 28, pp. 9-76.

Lewis, Helen B. 1971. Shame and guilt in neurosis. New York: International Universities Press.

Lewis, Mihael 1992. Shame: The Exposed Self. New York: The Free Press.

Loorits, Oskar 1955. The Jews in Estonian folk-belief. Yeda-àm. Journal of the Israel Folklore Society 3.1955, pp. 98-100.

Lutwak, Nita \& Panish, Jacqueline B. \& Ferrari, Joseph R. \& Razzino, Brian E. 2001. Shame and guilt and their relationship to positive expectations and anger expressiveness - Statistical Data Included. http:// www.findarticles.com/p/articles/mi_m2248/is_144_36/ai_84722690 Libra Publishers.

Moxnes, Halvor 2001. Honor and Shame. http://www.hendrickson.com/ pdf/chapters/1565632397-ch01.pdf

Muller, Roland 2000. Honor And Shame In A Middle Eastern Setting. http://nabataea.net/h\&s.html

Neyrey, Jerome H. 2000. Despising the Shame of the Cross: Honor and Shame in the Johannine Passion Narrative. http://www.nd.edu/ jneyrey1/ shame.html

Ochs, Ellinor \& Capps; Lisa 1996. Narrating the Self. Annual Review of Anthropology. 25, pp. 19-43.

Päärt, Villu 2004. Koolinoored tähistasid oktoobripühi sambaõhkimisega [The Youth Celebrate the October Festivities by Blasting a Monument]. Postimees 5. 11. http://www.postimees.ee/061104/kommentaarikeskus.php?ARTIKKEL_ID=149271\&TASK=KOMMENTAARID

Pakalns, Guntis 1995. Ghost Narratives in Latvia - Changes During Recent Years. Foaftale News. Newsletter of the International Society for Contemporary Legend Research, 37. June. 1-3.

Pakalns, Guntis 2004. Nõukogude inimene suudab kõike - jutustamisteema sotsialismi ja postsotsialismi ajastul [The Soviets are Almighty a Narrative Topic in the Socialist and Post-Socialist Era]. Kalmre, Eda (ed.) Kuuldust-nähtust. Tänapäeva folkloorist. Tartu: Eesti Keele Instituut. 
Plaat, Jaanus 2001. Usuliikumised, kirikud ja vabakogudused Lääneja Hiiumaal : usü̈henduste muutumisprotsessid 18. sajandi keskpaigast kuni 20. sajandi lõpuni [Religious Movements, Churches and Free Congregations in West-Estonia and Hiiumaa Island: Transitional Processes of Religious Movements from the Mid-18th Century to the Late 20th Century]. Tartu: Eesti Rahva Muuseum.

Rachman, S. J. 1990. Fear and courage. New York: W. H. Freeman and Company.

Sagris, Sven-Allan 2002. Kedagi ei ole õigust unustada. Rae Sõnumid. http://www.rae.ee/s6numid/2002/3/ava.htm

San Filippo, David 1994. What Is Fear? http://www.lutz-sanfilippo.com/ library/counseling/lsffear.html

Scheff, Thomas J. 1997. Shame in social theory. Lansky, R. L. \& Morrison, A. P. (eds.) The Widening Scope of Shame. London: The Analytic Press.

Scheff, Thomas J. 2004. Shame In Self And Society. Symbolic Interaction. In pront.

Scheff, Thomas \& Retzinger, Suzanne 1991. Violence and Emotions. Lexington, Mass: Lexington Books.

Sõtðov, Andrei 2004. Eesti õigeusu piiskopkond Stalini ajal aastail 19451953 [The Orthodox Diocese in Estonia during the Stalinist Period 19451953]. Tallinn: A. Sõtðov.

Tuval-Mashiach, Rivka \& Freedman, Sara \& Bargai, Neta \& Boker, Rut \& Hadar, Hilit \& Shalev, Arieh Y. 2004. Coping with Trauma: Narrative and Cognitive Perspectives Psychiatry. Interpersonal and Biological Processes. A Journal of the Washington School of Psychiatry. http:// www.extenza-eps.com / GPI/doi /abs / 10.1521 / psyc.67.3.280.48977

Usai, Urmas 1993 a, b. Eestlased tööpatalajonides 1941-1942. Mälestusi ja dokumente. I, II [Estonians in Labour Camps during 1941-1942. Memoirs and Documents. 1, 2]. Tallinn: Olion.

Viljandimaa 1939. Luha, A. \& Kant, E. \& Kruus, H. \& Tammekann, A. Viljandimaa. Eesti maateadusline, majandusline ja ajalooline kirjeldus [Viljandi County. Geographical, Economic and Historical Description of Estonia]. 7. Viljandi.

Wilde, P. E. 1766. Lühhike öppetus mis sees monned head rohhud täeda antakse, ni hästi innimeste kui ka weiste haigusse ning wiggaduste wasto, et se kellel tarwis on, woib moista, kuida temma peab nou otsima ning mis tulleb tähhele panna igga haigusse jures [A Short Instruction which informs of some good medicines for treating the illnesses and injuries of both humans and cattle, so that whoever needs it may understand how he is supposed to get advice and what needs to be noticed in case of each illness]. Pöltsamaa: P. E. Wilde. 